\title{
A DEFENSE OF THE NEGOTIABLE INSTRUMENTS LAW.
}

BX IYMAN D. BREWSTER,

PRESIDENT OF THE NATIONAT CONFERENCE ON UNIFORM IAWS.

It was with great pleasure that a sub-committee of the Conference of Commissioners on Uniform State Laws had the privilege of discussing the Negotiable Instruments Law with Professor James Barr Ames, the Dean of the Harvard Law School.

He had kindly consented, on request, to meet with us, at the annual session, at Saratoga, in August last.

It was with no less pleasure that, after two or three days re-examination of the Act, with reference to the criticisms of the Dean, we were able to report that, in our judgment, no change in the Act was needed and to have that report, after full explanation of the points discussed, unanimously approved by the Conference.

As the Dean has, with great courtesy, given us in advance substantially the same strictures to be published in the Harvard Law Review for December, 1900, it was suggested by members of the Conference that I should state in reply the reasons why the Conference did not adopt the views of the Dean. Finding that the Harvard Law Review could not publish a reply until late in the winter and that the YALE LAW JOURNAI could do so in January, I have availed myself of the early opportunity afforded of publishing it in this journal.

It is with diffidence that I undertake to reply to legal criticisms from such a source and upon such a subject. The Dean of the Harvard Law School has so long been, not merely an expert, but an authority, on this subject, that I would not rashly volunteer to attack his positions. But, sometimes the point of view is quite as important as extensive knowledge and I am constrained to believe that so keen a controversialist is somewhat affected by that "gandium certaminis" which the most open-minded advocate cannot wholly resist. Then too, 
if it is a question of experts, nearly all of them disagree with the Dean, on the main points at issue, as I shall try to show. If it is a question largely of practice and experience as a trier of cases, Professor Ames has none-while on the other hand, on all questions of custom and convenience, the practical knowledge of the hundred lawyers, and more, who framed the Negotiable Instruments Law, and the hundred bankers who adopted it, would seem to quite offset the mere conclusions of erudition.

One who, like Professor Ames, can approach the consideration of a legal subject from the purely academic point of view, unembarrassed by any preconceptions derived from practice at the bar, has a certain advantage in that the matter may present itself to his view in scientific arrangement and symmetry from the first. Yet on the other hand, the want of just that everyday familiarity with commercial affairs and business men, which every lawyer in considerable practicenecessarily acquires, sometimes unfits the mere scholar or book lawyer to see things as others see them, and may make him give undue weight to what is really of little or no importance. Accustomed to deal only with theoretical questions and to measure law by ideal standards, such a man may demand a fulness of expression which amounts to prolixity, and discern obscurities where to the ordinary lawyer or merchant everything would seem plain and simple.

But such questions are notsettled by the "Rule of Thumb," or a majority vote, and the Negotiable Instruments Act must stand on its own merits. It is a great good fortune to all concerned to have it tested by so great an expert.

Now as to the tests.

It is my purpose to devote this paper to answering the specific objections submitted in the Dean's article, grouping them as far as possible for the sake of brevity.

As five of the more important strictures are equally strict. ures of the English Act, which has been the Law of England since 1880 , the language being the same in both acts, the five can conveniently be considered together.

They are criticisms of sections 3-2, 9-5, 9-3, 29, 70. These sections in the Negotiable Instruments Law contain the following propositions :

(a) That a promise is not rendered conditional by "a statement of the transaction which gives rise to the instrument." 
(b) That an instrument is payable to bearer though it is "payable to the order of a fictitious person"-or payable to bearer;

(c) "Where the only or last indorsement is in blank."

(d) That "an accommodation party is one who has signed the instrument as maker, acceptor or indorser without receiving value therefor and for the purpose of lending his name to some other person."

(e) "That presentment for payment is not necessary in order to charge the person primarily liable on the instrument."

Answer. First, as a matter of authority, I know of no text book on bills and notes or any encyclopædia of law that does not hold the above propositions to be axioms of commercial law. They are sustained by a multitude of cases. Secondly, as to the inconveniences therefrom apprehended by the Professor, it is enough to say that none such have apparently arisen in England during the experience of twenty years, nor are any such apprehended by the bankers of this country, who after giving the matter very critical attention, have given their cordial approval of the law. Perhaps a more specific discussion of two of these five strictures, applicable to both the English and American Acts, will answer for a more minute criticism of the others. One is the critique on Sec. 29, and is as follows :

"Sec. 29 defines an accommodation party as one who has signed the instrument 'without receiving value therefor and for the purpose of lending his name to some other person.' By this definition, one who has received a commission, which is certainly value, for lending the credit of his name, would not be an accommodation party. The words, 'without receiving value therefor and' should be cancelled as inaccurate and misleading." The only difference I have been able to find between the language of the two Negotiable Instruments Laws and that of the ordinary definitions is that more of the text books and cases seem to use the words "without consideration" than the words "without value received." But as these expressions are made synonymous by the definitions in the Negotiable Instruments Law, Sec.191, all the text books and modern cases agree with the Negotiable Instruments Act, as to absence of consideration. The definition in the Negotiable Instruments Law is the definition given in the new edition of the American and English Encyclopredia of Law, Vol. I, pages 335-6:

This article is a very full and complete discussion of the subject, containing fifty-eight pages on accommodation parties 
alone. Daniel is to the same effect. 1 Daniel 189. So also Tiedman, Sec. 158. Byles on Bills, star paging 131. 2 Randolph 472. Norton's Horn-Book (1900) 176. Bigelow, second edition, cites the definition given by the Negotiable Instruments Law as the true definition. On page 336 of the second Encyclopædia, supra, the language is, "there must be an absence of consideration between the accommodated and the accommodation party." Rawle's Bouviet's definition is "Bills or notes made, accepted or indorsed without any consideration." Not only do the opinions of the judges, text books, statutes, codes, and the law dictionaries agree on this point, but it is worthy of notice that the last leading lexicons agree exactly with the definition of the Negotiable Instruments Law so far as absence of consideration is concerned. (See last Standard and Webster ad verbum.) The only reason given for the overthrow of all these authorities is an illustration intended apparently to demonstrate the difficulty of showing what is value and what is not, but which in reality indicates value on its face. What is there "in accurate and misleading" in a definition universally adopted?

Sec. 3-2, which provides that "an order or promise is not rendered conditional by the addition of a statement of the transaction, which gives rise to the instrument" is objected to as "unmeaning" and "nullifying several decisions." Here, as before, the text books and modern cases are almost unanimously against the Dean.

The instance cited by him of a note "given as collateral security" contains notice upon its face that the note is not an unconditional promise to pay, but conditional upon the nonpayment of the principal debt. (See Sec. 1, Par. 2).

The provision was intended to cover such transactions as a "chattel note," in order to unify the law, which has been held differently, as Dean Ames shows in the cases which he cites. The decision in New York, cited by him, to prove that the Negotiable Instruments Law did not cover such a note, Third Bank v. Spring, 28 N. Y. Mis. 9 , has since been reversed, s. c. $63 N$. Y., Supp. 410, although the Apfellate Division did not base its reversal on the terms of the act. The latter decision, therefore, implies that the terms of the act have not changed the law in New York. How the provision is "obscure, inartistic and useless," as claimed by the critic, does not appear. That it is not very "obscure" seems certain or some question would have arisen under it in twenty years. Good, clear, plain English would seem to be "artistic" 
enough for the language of a statute. A single line which settles many discordant decisions would not ordinarily be termed "useless" or, on any interpretation, "mischievous."

The other three propositions, " $b$, c and $f$ " can easily be tested in the same way by reference to the same standard authorities. In fact I do not see how any good practical commercial lawyer could regard them as questionable. I shall notlumber up this reply with scores of citations of cases. The text books on these plain propositions are fully supported by the cases cited by them.

But I must condense. Of the sections of the law criticized by the Dean other than " $a$ " and " $d$," already considered at length, I can best justify the conclusions of the Conference by repeating, as near as can be remembered, the off hand answers given at the time of the friendly discussion aforesaid. The fullest notes are those of Chief Justice Stiness of Rhode Island, who was chairman of the sub-committee and has favored me with the privilege of using them. I have used them freely, making only such necessary changes as any new point in the Dean's Harvard article suggests. I take these notes in the order of the criticisms made by the Dean. The general soundness and practical wisdom of these answers, or rather of the propositions they defend, will, I believe, be confirmed by a careful examination of the best authorities.

Sec. 36-2-3. The point here made is that there is no difference between an agent and a trustee, because the agent would collect for the benefit of his principal. Hence " 2 and 3 should be consolidated." All agents are, in a sense, trustees, because they are ultimately accountable to the principal. Butall agents are not technically trustees. The distinction between an agent and a trustee is embodied here for the purpose of relieving a plaintiff from proving an actual trust, which would be necessary under Professor Ames' proposed substitute. A general agent might be authorized to use money quite differently from a trustee.

Sec. 137. This section holds the destruction of a bill, or a refusal to return it, equivalent to an acceptance. He concedes that a drawee, so misconducting, should be liable for a conversion. A destruction or refusal to deliver a thing is, in law, a conversion. The Dean says this section makes a refusal to accept, an acceptance, and adds, "such a perversion of language would be strange enough anywhere, but in a deliberately framed code is well-nigh inexplicable." Surely this is a mere play upon 
words. There has been no "refusal to accept," simply a "refusal to return within twenty-four hours." This provision was adopted in New York by statute fifty years ago.

Sec. $9-3$, is criticized because it holds a note, payable to a fictitious or non-existing person, as payable to bearer. If one issues his note to a fictitious person, why should it not be treated as a note to bearer, for there is no one who can indorse it? Surely it is more logical to hold that a note, which purports to be payable to a person, when there is no such person and the maker knows it, must have been intended to be payable to bearer, than to hold that somebody must assume the name of such fictitious person, and make a false indorsement in order to give title to the note. The case supposed by Dean Ames, of a thief stealing such a note and the consequent hardship upon the maker of liability on the note as payable to bearer, when he would not be liable, because of incompleteness, if an indorsement were required, would be a rare one. His criticism seems to imply that the Act should cover rare and imaginary exceptions rather than serve the commendable purpose, which he concedes that the section has, of providing for common cases, such as notes payable to unincorporated associations, estates of deceased persons, and the like. Under his proposed substitute, if the maker completes the indorsement the same result would follow as without it. In either case, the familiar rule, that where one of two innocent parties must suffer loss, it should fall on him who has given the occasion for it, seems to be far short of "cruel injustice." There has been a variety of decisions in regard to stolen notes. 1 Dan. Neg. Inst., chap. 26 , 4th ed. This section would result in a definite rule; and, being in the line of aiding negotiability, a rule which puts the loss on a man who makes notes, for fun or fraud, and leaves them so that they can be stolen and issued, rather than on one who, in due course, has taken a maker's written promise to pay, seems to be a just one. The honesty of one's holding can always be examined.

Sec. 9-5. The first objection is that it covers a note payable to $\mathrm{B}$ and indorsed by $\mathrm{C}$ in blank. Such a construction is impossible. The section clearly means that a note duly transferred and indorsed in blank, is then payable to bearer; a proposition too clear for argument, so long as the indorsement remains in that form. As Dean Ames says: "It ceases to be payable to bearer if afterwards indorsed specially." The reason why such a rule is "illogical and undesirable" is not clear. 
The third objection is that if, after a special indorsement, the note is transferred by delivery, the transferee cannot sue parties prior to the special indorser in his own name, but only in the name of his assignor. This is an assumption not contained in the Act. On the contrary, the effect of Par. 40, which authorizes a transfer by delivery, seems to give the transferee a right to sue in his own name, otherwise the note would not be "negotiated" within the meaning of the Act. The only limitation is that the person indorsing specially is liable as indorser only to such holders as make title through his indorsement. The proposed substitute appears to mean exactly what the Act means, since Par. 48 gives the right to strike out any indorsement not necessary to title. See also Par. 34 of Negotiable Instruments Law.

Sec. 20. The case supposed in the objection fails to show injustice. It is, if A signs a note as agent for B, mistakenly believing that he has authority, and $B$, a bankrupt, denies the agency, the payee should only recover from $A$ what he might have recovered from $B$, the bankrupt, whereas the Act makes A liable for the face of the note. The plain answer is that one signing a note as agent for another should know and be able to show his authority. If he signs without authority, he alone in fact, and so in law, is the maker of the note, and he should be held liable accordingly.

Sec. 22, as to an infant's indorsement, is the same as in the English Act, except that the words "passes the property therein" are used in place of the words "entitles the holder to receive payment of the bill and to enforce it against any other party thereto." As the the scope of the Act is confined to negotiable instruments, it does not otherwise affect the law relating to infants. Hence, the words of the two acts are equivalent in meaning, with the advantage of conciseness in the American Act.

Sec. 34 follows the English Act. Dean Ames puts the question whether if the payee writes: "I assign this note to $B$, or I guarantee to B the payment of this note," he would be liable on his assignment, or guaranty, and regrets that the Act does not answer the question. The liability of a party on a peculiar indorsement, which is outside of negotiability, must be settled by a court.

Sec. 37-2. The supposed injustice of this sub-section, in case the indorsement was for value to the indorsee in trust for a third person, is not apparent. 
Sec. 40 is claimed to be repugnant to Par. 9.5, but this is not so. 9-5 declares a note to be payable to bearer when its last indorsement is in blank; 40 relates to a note where the last indorsement is special, and provides that it may then be transferred by delivery, in order to cover cases of good faith where title is frequently passed in that way, by persons ignorant of mercantile usage. In the case of a theft of a note from a special indorsee, which Dean Ames supposes, what harm can result? As before stated, the section validates a transfer by delivery, without the indorsement of the special indorsee, and so gives the holder a right to sue in his own name. This plainly implies proof of delivery from the owner, which would protect the parties in case of loss or theft of the note.

The first sentence of Sec. 40 is as follows :

"Where an instrument, payable to bearer, is indorsed specially, it may nevertheless be further negotiated by delivery; but the person indorsing specially is liable as indorser to only such holders as make title through his indorsement."

Sec. $9-5$ reads :

"The instrument is payable to bearer: * * * when the only or last indorsement is in blank."

The Dean's stricture on the assumed repugnancy of these two sections begins, "Sec. $40^{* * * *}$ provides that an instrument indorsed in blank, although subsequently indorsed specially, may nevertheless be further negotiated by delivery." But as a comparison shows, Sec. 40 does not refer to an "instrument indorsed in blank" but to an instrument "payable to bearer." The supposed inconsistency of the two sections arises entirely from the mistaken quotation of the learned Dean.

The first sentence of Sec. 49 is as follows:

"Where the holder of an instrument payable to his order transfers it for value, without indorsing it, the transfer vests in the transferee such title as the transferrer had therein, and the transferee acquires in addition, the right to have the indorsement of the transferrer." This section gives the transferee such title as the transferrer had and the right to have an indorsement.

This is quite right. The holder in such a case, not taking title in the usual way by indorsement, may well be charged with notice of any defect in the title to the note, or of equities between the parties. The clause giving the right to require an indorsement could only be enforced in equity, upon proof of an 
agreement to that effect. Hence, the words added in the Colorado statute, "if omitted by accident or mistake" were unnecessary. An indorsement so enforced would complete the title and thus cover the case of hardship which Dean Ames supposes. All cases of possible equities cannot be covered by legislation.

Sec. 64 provides that one, not otherwise a party to an instrument, who puts his signature thereon before delivery, is liable as an indorser. It is to cover cases where persons put their names on the back of notes before delivery, and where they have been variously held to be indorsers, guarantors and joint makers. The section makes the rule that he shall be liable to all subsequent parties. Dean Ames says he should be liable to the maker or drawer whom he has accommodated with his signature, in cases where the maker or drawer is the payee. Apparently, his idea is that if he is not liable to the drawerpayee, no title can be passed by the latter. But sub-section 2 makes the party liable as indorser to all parties subsequent to the maker or drawer. The Dean's proposed substitute would defeat the purpose of the Act, which is to put the irregular party into the place of the indorser, by making him practically a joint promoter, because his signature would precede that of the indorser.

Sec. 65 makes a person, who transfers a note by delivery or by a qualified indorsement, warrant certain things. It then says: "But when the negotiation is by delivery only, the warranty extends in favor of no holder other than the immediate transferee." Dean Ames objects that this last clause makes the waranty of the indorser, which is that of a vendor, run in favor of all subsequent holders, which he says is "an original invention of the Negotiable Instruments Act. But this is its only merit."

The Dean is tunjust to himself. In 2 Ames, Cases on Bills and Notes, Index under head of "Indorser without recourse," 840,882 , is this syllabus: "An indorsement without recourse, like a transfer by delivery merely, being, in substance, a sale, the indorser is responsible to the indorsee and subsequent holders for the validity of the title and the genuineness of the instrument which he purports to sell." The selected case is Blethen $\mathrm{v}$. Lovering, $58 \mathrm{Me}$. 240. It was not a case of subsequent parties, but the long note appended to it does not in this respect distinguish the case from the syllabus in the Index. 
The same rule is stated so far as relates to a qualified indorsement in Fourth Am. \& Eng. Encyclopædia of Law, second edition, 481, in almost the same words, and in 1 Daniel on Negotiable Instruments, fourth edition, Par.670, the language is: "The holder may sue the indorser." This is enough to show that the framers of the Negotiable Instruments Law must disclaim the credit of the invention which is accorded to them.

In the new Norton on Bills and Notes, (horn-book series) page 167 , the editor gives the sub-section in question from the Negotiable Instruments Law as the true law on qualified indorsements, quoting 2 Ames, Cases on Bills and Notes, 84,0,882, as his authority. He seems to doubt however whether, among the conflicting cases, it was the law before made so by the Negotiable Instruments Law. He also thinks that the law laid down by Professor Ames in the passage above quoted that the warranty of the transferrer by delivery also extends to subsequent parties, while not accepted as law elsewhere, ought to be the law. So that, instead of being guilty of the heinous crime of "novelty," the Negotiable Instruments Law is, on this matter, more conservative than either the Norton Horn-Book or Dean Ames' leading cases, when it lays down the rule, that "when negotiation is by delivery only, the warranty extends in favor of no holder other than the immediate transferee." The reasonableness of making a distinction between a transferrer by delivery and an indorser without recourse, because in one case the name is on the paper and in the other is not, may or may not be doubtful. Norton's Horn-Book, Sec. 79, says they stand "much upon the same footing;" Dean Ames says their liability is identical. But that a certain and definite rule should be adopted, nobody can doubt. 1

\footnotetext{
1 On this point I have cited chiefly the new Norțon Horn-Book, on Bills and Notes, just edited by Mr. Francis B. Tiffany, not only because it is one of the ablest and most interesting discussions on this special point, but because the editor seems to have taken most of the new matter in the book equally from the Negotiable Instruments Law and Professor Ames' Leading Cases on Bills and Notes. The preface says: "The present editor wishes to express lis great obligation to Professor Ames, whose Index and Summary at the end of the cases, unquestionably the most important contribution to the subject that has been made in America, he has constantly consulted." It is bence, doubly reassuring to note that with so orthodox an authority for "constant" reference, as the Leading Cases on Bills and Notes, Mr. Tiffany quotes a score of definitions bodily, from the Negotiable Instruments Law, and so far as I have observed, does not seem to disegree with its statement of law on any point.
} 
Sec. 66 is more explicit and does make a change in the law, but it is in the line of aiding negotiability. It follows the English Act (Par. 55) in holding an indorser liable to a holder in due course, as to genuineness and regularity, and extends the liability only as to the warranty that the note was valid at the time of his indorsement. As a note usually gets its strength from the names of its indorsers, it seems to be just that the warranty should be included, if, indeed, it really adds anything to the English Act.

Sec. 68 treats joint-payers and indorsers, who indorse, as indorsing jointly and severally. Theoretically, this may, as the Dean says, "seem to be a blunder." But, practically, it is a convenience in suing, and was, doubtless, inserted for that purpose.

Sec. 70 provides that presentment for payment is notnecessary to charge the person primarily liable on the instrument. The section was intended to apply to the maker of a note, who, of course, is liable if he does not pay according to its tenor. But, the Dean says, "it should except the cases of bank notes and certificates of deposits." In view of the fact that no person would be likely to bring a suit on such instruments when he could get the money at the bank, and the further fact that no harm could come to the promisor, excepting as to costs which are in most, if not all the States, subject to the discretion of the court, the objection does not seem to be practical.

Sec. 119-4 provides that an instrument is discharged by an act which will discharge a simple contract for the payment of money. The objection is that if the holder of a note accepts a horse in satisfaction, before maturity, and then transfers the note, the maker is still liable. The section evidently relates to acts between the parties. If the maker allows his note to remain outstanding, and so to be transferred, of course he should be held liable.

Sec. 120-3 discharges a person secondarily liable by the discharge of a prior party. This too, evidently, means some act between the parties. The law has long been settled that the discharge of the liability of a bankrupt maker of a notedoes not affect the liability of the other parties on the note. It is generally held that the statute of limitations against an indorser runs, not necessarily from the date of the note, but from the time when the indorser's liability accrues. When, therefore, the language of sub-section 3 is used (exactly as given in a 
number of the text-books), it of course refers to a discharge by the holder and not a discharge by act of the law, as the whole context, referring to acts of the parties and not to any acts of the law, clearly indicates. Thus Randolph, second edition, Sec. 769, says "the release of a prior indorsement discharges subsequent indorsers," assuming of course their release by the holder. That this is the natural meaning and interpretation of sub-section 3 , Sec. 120 , is fairly inferrible from this fact. Ten books on commercial paper have been published since the Negotiable Instruments Law was legislatively adopted. All of them treat more or less fully of that law; Huffcut, Randolph, Bigelow, Norton, generally, and Selover and Crawford and the special books on the New York and Colorado Acts, treating of that Act alone. Not one of these ten authors intimates that sub-section 3 has changed the law in the slightest degree. In all the reports of the various Commissioners to their respective States, elaborately stating every change of law made by the Negotiable Instruments Law, no allusion is made to sub-section 3 .

It is not necessary in this instance to invoke the aid of the rule of law stated in Sutherland on Statutory Construction, Sec. 156, that codes which condense and reaffirm in general, the rules of the common law, do not repeal the exceptions to these rules which they reaffirm; or the similar doctrine in Endlich on Statutes, sections 127-205, that in statutes or revisions condensing or in general re-stating the common law, no change is presumed except by the clearest and most imperative implication. ${ }^{2}$ How far this doctrine is carried in England, in regard to the Bills of Exchange Act is shown in the case of Bank of England v. Vagliano, L. R. 1891, Appeal Cases, page 144. But were this doctrine invoked the simplest application of the rule or of Sec. 196 would at once relieve the sub-section in question of the misinterpretation put upon it by the Dean. Nevertheless our critic, whose adjectives here and there are surprisingly vigorous, describes this aphorism of the Law

\footnotetext{
2 Because of the necessity of preserving this presumption in all its integrity, the stub-committee declined to accept some slight changes proposed by the Dean, such as adding to sub-section 120-3 the words, "by the holder." It would be (1) assuming a doubt where we had no doubt, and (2) assuming the doctrine from Sutherland and Endlich, supra, not to be true. A doctrine without strict adherence to which codes would have to be as long as text-books.
} 
Merchant as, " the most mischievously revolutionary provision of the new code." 3

As to sub-sections 5 and 6 of Sec. 120, the objection of inaccuracy is based upon the case of an accommodation drawer or indorser, because he says that the authorities are unanimous against the discharge of the party accommodated. Undoubtedly that is so, and it is difficult to see how the law could be construed to cover such a case. The law is intended to set out the legal liability on the instrument, as such, in the due course of commercial transactions. It could never be held to mean that a party who had paid money for another's accommodation could not, at law, if not on the instrument, recover it back. That is a matter between the parties, entirely outside of the effect of the instrument in the hands of a holder.

Sec. 175 is the same as in the English Act, and whatever may have been the difference in English decisions, it was, doubtless, deliberately adopted, and certainly it seems to be just. One who pays for the honor of the drawer is as much an accommodation party as the accommodation acceptor and has no equity superior to that of the latter. But even if Mr. Chalmers and Mr. Crawford are wrong in preferring the law of Lords Kenyon and Erskine to that of Lord Loughborough, and Malins V. C., now that Lord Kenyon's ruling is the law of Great Britain and has been followed in sereral of the States (see cases cited in note 2, page 499, vol.4 of second edition of Am.\& Eng. Ency. of $L a w)$ and as uniformity is one of the main objects of the Negotiable Instruments Law, no mistake is made in leaving Sec. 175 as it stands.

Sec. 186. The objection is that, under Par. 89, upon presentment and dishonor notice must be given to the drawer of a check or he will be discharged. Suppose it is so, technically, with reference to the check itself. What is the harm? The debt is not discharged, except for laches. The holder can sue on his debt just the same as he could have done before the check was given. In some States a check is not held to be

\footnotetext{
8 The reasons attributed by the Dean for one or two of the changes of the law, made in the Negotiable Instruments Law are, I think, misapprehensions. I expected to have received from Mr. Crawford, the draftsman, a paper stating the real grounds for such changes, in his own mind, but pressure of business on his part has prevented him from rendering any assistance during the brief time allowed for the preparation of this article, and the same is true of my colleagues on the committee. So the responsibility for any heresies in this paper must rest on my own shoulders.
} 
enough of a negotiable instrument to sustain an action. It is held as an order, with no promise to pay. The section seems to be harmless in any view.4

So much by way of comment on the criticisms of the Dean. It is quite possible that on some of the more technical and academic criticisms we have above discussed, the weight of authority or the true theory of the Law Merchant may be on the side of the critic. But let any candid reader carefully go over the "salutary changes" and "settlements of controverted questions" (and he might have added twice as many more) so admirably stated by the Dean in the commencement of his article, and the defects he assumes (if they are defects) are like spots on the sun. It takes an expert to see them, and he must use glasses at that.

In conclusion, our critic remarks that "if the preceding criticisms are well founded, the errors and imperfections in the Negotiable Instruments Law are so numerous and so serious that, notwithstanding its many merits, its adoption by fifteen States must be regarded as a misfortune." May we not say in reply that if the Dean's criticisms are not well founded, especially if, in fact, they have no practical basis at all, its speedy adoption by all of the States would be, as Lord Herschell has expressed it, "a boon to the commercial communities of both nations."

The critic relieves the severity of his adverse conclusion by stating that the Commissioners made a mistake in not securing an abundance of competent criticism, both public and private, from widely different sources, before issuing with their sanction the final draft of the proposed law. It is enough to state in reply that no statute in the English language, so far as I know, has received a tithe of the elaborate work laid out on the Negotiable Instruments Law. I have described before in this journal (6 YALE LAW JouRNaL, February, 1897, page 132) how the preparation of the original law involved the work of more than one hundred trained lawyers, the co-operation of the mer-

4 One would like to accept the challenge on page 24.4 in the Dean's article on the true theory on which a code on negotiable instruments should be made. Although this to be sure is rather a criticism of Chalmers and Herschell, Selborne and Bramwell, than of Mr. Crawford and the Conference. One would also like to explain why the subject of "Conflict of Laws" and some other subjects suggested by the Dean as omissions, "Marring the symmetry of the new code" were properly omitted in so short and compact a statute, which it was hoped would be adopted by all the States and so leave much less inter-State conflict. But the space given me does not permit. 
cantile community for years in its evolution, and its critical consideration by both Houses of Parliament. In this country, it has had the criticism of lawyers in the Commissions from thirtytwo States, who had it in consideration for more than a year during its preparation, and of leading text writers and teachers on the subject of bills and notes, including from Massachusetts alone Professors Bigelow, Williston, and Bennett, the wellknown law writer, Ieonard A. Jones, and the author of "American Statute Law," Mr. F. J. Stimson.

Six months before its adoption, copies were sent to many of the law schools (it was supposed to all), and to all of the known writers on bills and notes in the country. It has been adopted as a text-book in several law schools. It has been recommended for adoption by the Supreme Courts of South Carolina and Rhode Island in their opinions, before it was adopted by their Legislatures, and so far as I know it has yet to meet its first adverse criticism from any of the Courts in the seventeen extensive jurisdictions where it has been adopted. It has been critically examined and thereafter recommended by the very able committees of the New York City Bar Association and the Pennsylvania Bar Association, and by the Judiciary Committees of over twenty States. With this unqualified indorsement of its value, is it unreasonable to anticipate its acceptance before many years by all of the States of the Union?

But wherever passed, it should be passed without any alteration whatever, exactly like the original code recommended by the Commissioners, word for word. Otherwise, the discrepancies of supposed uniformity would be almost as bad as the present diversity. Once passed, it should not be changed until some Court of authority has indicated the desirability of a change, or some convention of bankers or merchants has indicated where the demands of modern business require a change. 